\title{
Respon Pertumbuhan dan Produktivitas Dua Varietas Padi (Oryza sativa L.) pada Sistem Tanam Mekanis dan Manual
}

\author{
Growth Response and Productivity of Two Rice Varieties (Oryza sativa L.) \\ on Mechanical and Manual Cultivation Systems \\ Asis*, Rizki Ardiansyah, dan Rachman Jaya \\ Balai Pengkajian Teknologi Pertanian Aceh \\ J1. Panglima Nyak Makam No. 27 Lampineung-Banda Aceh, Aceh 23125, Indonesia
}

Diterima 9 Juni 2021/Disetujui 10 Agustus 2021

\begin{abstract}
Plant cultivation techniques using agricultural mechanization (rice transplanter planting machines) and early-maturing and high yielding varieties may increase crop productivity and farmers 'income. The application of the rice transplanter jajar legowo can increase rice crop productivity and planting costs by increasing the plant population and reducing labor and planting time. This study aimed to determine the growth and productivity of Inpari 32 and Inpari 42 varieties with different techniques in irrigated land. This research was conducted from April to July 2019 in Aneuk Glee Village, Indrapuri District, Aceh Besar using a randomized complete block design (RCBD) with two factors and four replications. The factors were varieties (V) consisting of Inpari 32 (V1), Inpari 42 (V2), and planting technique (T) consisting of a transplanter machine (T1), tile machines (T2), and manual (T3). Variety and planting techniques did not affect plant growth and productivity, but the variety had a significant effect on the average number of tillers, number of panicles, and plant productivity, with Inpari 32 variety showing the best results. Planting technique factors did not affect plant growth and productivity.
\end{abstract}

Keywords: jajar legowo, mechanization, planting distance, tiles, transplanter

\section{ABSTRAK}

Teknik budidaya tanaman menggunakan mekanisasi pertanian (mesin tanam rice transplanter) dan varietas berumur genjah dan produksi tinggi dapat meningkatkan produktivitas tanaman dan pendapatan petani. Penerapan rice transpanter jajar legowo dapat meningkatkan produktivitas tanaman padi dan menghemat biaya penanaman melalui peningkatan populasi tanaman pengurangan jumlah tenaga kerja dan percepatan waktu tanam. Penelitian ini bertujuan untuk mengetahui pertumbuhan dan produktivitas varietas Inpari 32 dan Inpari 42 dengan teknik penanaman berbeda di lahan irigasi. Penelitian ini dilaksanakan pada bulan April-Juli 2019 di Desa Aneuk Glee, Kecamatan Indrapuri, Aceh Besar, menggunakan rancangan kelompok lengkap teracak (RKLT) dengan dua faktor dan empat ulangan. Faktor pertama yaitu varietas yang terdiri dari Inpari 32 (V1), Inpari 42 (V2), dan faktor kedua yaitu teknik penanaman yang terdiri dari mesin rice transplanter jarwo (T1), mesin rice transplanter tegel (T2) dan manual (T3). Varietas dan teknik penanaman tidak berpengaruh nyata terhadap pertumbuhan dan produktivitas tanaman, tetapi varietas memiliki pengaruh signifikan terhadap rata-rata jumlah anakan, jumlah malai, dan produktivitas tanaman, dengan varietas Inpari 32 menunjukkan hasil terbaik. Faktor teknik penanaman tidak berpengaruh terhadap pertumbuhan dan produktivitas tanaman.

Kata kunci: jajar legowo, jarak tanam, mekanisasi, tegel, transplanter

\section{PENDAHULUAN}

Penduduk Indonesia tahun 2014 berjumlah 252.2 juta jiwa, bergerak mencapai 265 juta jiwa tahun 2018 dengan pertambahan $1.27 \%$ per tahun, sedangkan produksi beras gabah kering giling (GKG) tahun 2019 sebesar 54.60 juta

\footnotetext{
* Penulis untuk korespondensi. e-mail: asissp_89@yahoo.co.id
}

ton. Ketersediaan produksi dalam bentuk beras dari produksi GKG diperkirakan sebesar 32.41 juta ton dengan kebutuhan konsumsi nasional sebesar 29.78 juta ton, sehingga surplus beras sebesar 2.6 juta ton. Pertumbuhan penduduk Indonesia yang mengalami peningkatan secara cepat setiap tahun tidak diikuti dengan peningkatan produksi beras nasional yang cenderung melambat karena berkurangnya luas lahan produksi dan produktivitas tanaman yang peningkatannya sudah melandai (BPS, 2019). 
Salah satu teknologi budidaya yang dapat mempengaruhi produksi tanaman adalah jarak tanam dan teknik penanaman sehingga dapat meningkatkan populasi tanaman per luasan lahan. Teknologi budidaya yang menekankan pada peningkatan populasi tanaman adalah pola tanam jajar legowo (jarwo). Pola tanam jajar legowo dapat diterapkan dengan penggunaan rice transplanter yang dapat menghemat biaya penanaman dengan berkurangnya jam kerja penanaman dan mempercepat waktu penanaman. Hasil penelitian Harnel (2012) menunjukkan bahwa biaya pokok penggunaan mesin tanam transplanter Rp. $325,057,-$ ha $^{-1}$, sedangkan biaya penanaman manual adalah Rp. 653,343,- ha-1 sehingga titik impas alat tanam bibit padi adalah 13.46 ha per tahun relatif kecil. Titik impas merupakan kemampuan alat tanam bekerja minimal pada lahan sawah sehingga berada pada kondisi tidak menguntungkan tetapi tidak merugikan, berdasarkan biaya tetap, biaya tidak tetap dan biaya pokok alat tanam padi. Hal ini menunjukkan bahwa penghematan waktu dan tenaga kerja dapat mengurangi biaya penanaman sehingga dapat meningkatkan pendapatan petani.

Selain itu, penerapan rice transplanter dapat mendukungupayaintensifikasipertaniandengan peningkatan indeks pertanaman (IP) 200 menjadi IP 300. Pengembangan IP 300 dapat tercapai dengan penerapan budidaya secara terpadu melalui aplikasi pengolahan lahan yang tepat, pemupukan organik dan anorganik, biodekomposer, seed treatment, persemaian di luar areal budidaya (sistem dapog), dan pengendalian organisme pengganggu tanaman (OPT) secara terpadu dan panen menggunakan mesin combine harvester.

Selain itu, faktor varietas merupakan hal yang sangat penting untuk mendukung IP 300 pada komoditas padi karena umur tanaman dan produktivitas ditentukan oleh varietas. Varietas padi sawah memiliki umur panen berbedabeda sesuai dengan deskripsi tanaman (Balitbangtan, 2020). Syahri dan Somantri (2016) menyatakan bahwa penggunaan varietas unggul berkontribusi nyata terhadap peningkatan produksi sehingga perlu dilakukan penyebarluasan penggunaan varietas unggul dan ketersedian benih ditingkat petani. Penelitian ini sangat penting dilakukan untuk mendapatkan teknik penanaman yang optimum dan kesesuaian varietas dengan sistem tanam dan capaian produktivitas yang diharapkan. Penelitian ini bertujuan untuk mengetahui pertumbuhan dan produktivitas varietas Inpari 32 dan Inpari 42 dengan teknik penanaman berbeda sehingga dapat digunakan sebagai teknologi budidaya padi yang optimum di lahan irigasi.

\section{BAHAN DAN METODE}

Penelitian ini dilaksanakan pada bulan April-Juli 2019 di Desa Aneuk Glee, Kecamatan Indrapuri, Aceh Besar. Penelitian ini menggunakan rancangan kelompok lengkap teracak (RKTL) faktorial, yaitu faktor varietas terdiri dari $\mathrm{V} 1$ = Inpari 32, dan V2 = Inpari 42, dan faktor teknik penanaman terdiri dari $\mathrm{T} 1=$ sistem jarwo $2: 1, \mathrm{~T} 2=$ sistem tegel, dan T3 = Manual (T1 dan T2 ditanaman menggunakan rice transpanter) yang diulang sebanyak 4 kali sehingga terdapat 24 unit percobaan ( $15 \mathrm{~m} \times 15 \mathrm{~m}$ per unit percobaan) dengan 10 sampel pengamatan per perlakuan.

Penelitian diawali dengan pengolahan tanah pada lahan kering dan basah untuk memperbaiki struktur lahan, yang diaplikasi biodekomposer dengan dosis $2 \mathrm{~kg} \mathrm{ha}^{-1}$ untuk mempercepat pelapukan. Pemupukan dengan pupuk organik (kandang) dengan dosis 2 ton $\mathrm{ha}^{-1}$ pada saat pengolahan tanah basah. Lahan didiamkan selama seminggu untuk meningkatkan daya serap air pada lahan setelah dilakukan pemupukan. Persemain bibit dilakukan pada areal luar lahan budidaya sehingga mempercepat kesiapan lahan untuk ditanami. Persemaian dilakukan menggunakan dapog (tempat persemaian) dengan ukuran $18 \mathrm{~cm}$ x $56 \mathrm{~cm}$ sesuai dengan mesin tanam padi pola tanaman jarwo $2: 1$. Benih diberi pupuk hayati sebelum tanam untuk meningkatkan pertumbuhan bibit sebanyak 20 g per 1 (satu) kg benih. Bibit yang siap tanam (21 hari setelah tanaman (HST)) dilakukan penanaman menggunakan mesin transplanter pola jajar legowo 2:1, mesin tegel dan manual sesuai dengan mekanisme pengujian sistem tanam padi sebanyak 2-3 bibit per lubang tanam. Kebutuhan benih yang direkomendasikan pada sistem tanam jarwo 2:1 adalah $25 \mathrm{~kg} \mathrm{ha}^{-1}$.

Jarak tanam pola jajar legowo 2:1 yaitu $25 \mathrm{~cm} \times 12.5$ $\mathrm{cm}$ x $50 \mathrm{~cm}$ (populasi 213,333 rumpun per hektar), sistem tegel (mesin dan manual) yaitu $25 \mathrm{~cm} \mathrm{x} 25 \mathrm{~cm}$ (populasi 160,000 rumpun per hektar). Pemupukan NPK majemuk (16:16:16) dengan dosis $300 \mathrm{~kg} \mathrm{ha}^{-1}$ diaplikasi pada tanaman umur 14 dan 40 HST dengan cara menyebar pupuk di atas permukaan lahan. Tanaman dilakukan penyiangan dari gulma dan pengendalian hama dan penyakit secara terpadu untuk mengatasi rendahnya produksi tanaman akibat serangan organisme pangganguu tanaman.

Variabel yang diamati, yaitu tinggi tanaman $(\mathrm{cm})$ umur 14, 21, dan 56 HST, jumlah anakan umur 14, 21, dan 56 HST, panjang malai $(\mathrm{cm})$, dan jumlah malai, jumlah gabah per malai, bobot 1,000 biji $(\mathrm{g})$, bobot gabah per rumpun $(\mathrm{kg})$ dan produktivitas (ton $\mathrm{ha}^{-1}$ ) pada kadar air 14\% dengan pengambilan sampel secara ubinan dengan luas 12 $\mathrm{m}^{2}$. Hasil pengamatan dianalisis dengan analisis sidik ragam (ANOVA) $\alpha=5 \%$, dilanjutkan dengan uji nyata jujur (BNJ) pada taraf $\alpha=5 \%$.

\section{HASIL DAN PEMBAHASAN}

\section{Tinggi Tanaman}

Hasil analisis sidik ragam menunjukkan bahwa perlakuan varietas dan teknik penanaman tidak berpengaruh terhadap tinggi tanaman umur 14, 21, dan 56 HST. Hal ini menunjukkan bahwa varietas Inpari 32 dan Inpari 42 memiliki kemampuan tumbuh yang sama pada lahan irigasi dengan berbagai teknik penanaman. Keragaan tinggi tanaman varietas Inpari 32 dan Inpari 42 ditampilkan pada Gambar 1. Deskripsi varietas Inpari 32 dan Inpari 42 menunjukkan kedua varietas memiliki rata-rata tinggi tanaman yang relatif sama yaitu $97 \mathrm{~cm}$ dan $93 \mathrm{~cm}$ (Balitbangtan, 2020).

Tanaman padi mampu beradaptasi pada teknik penanaman yang berbeda sehingga memiliki rata-rata tinggi tanaman yang tidak berbeda. Hal ini menunjukkan bahwa 


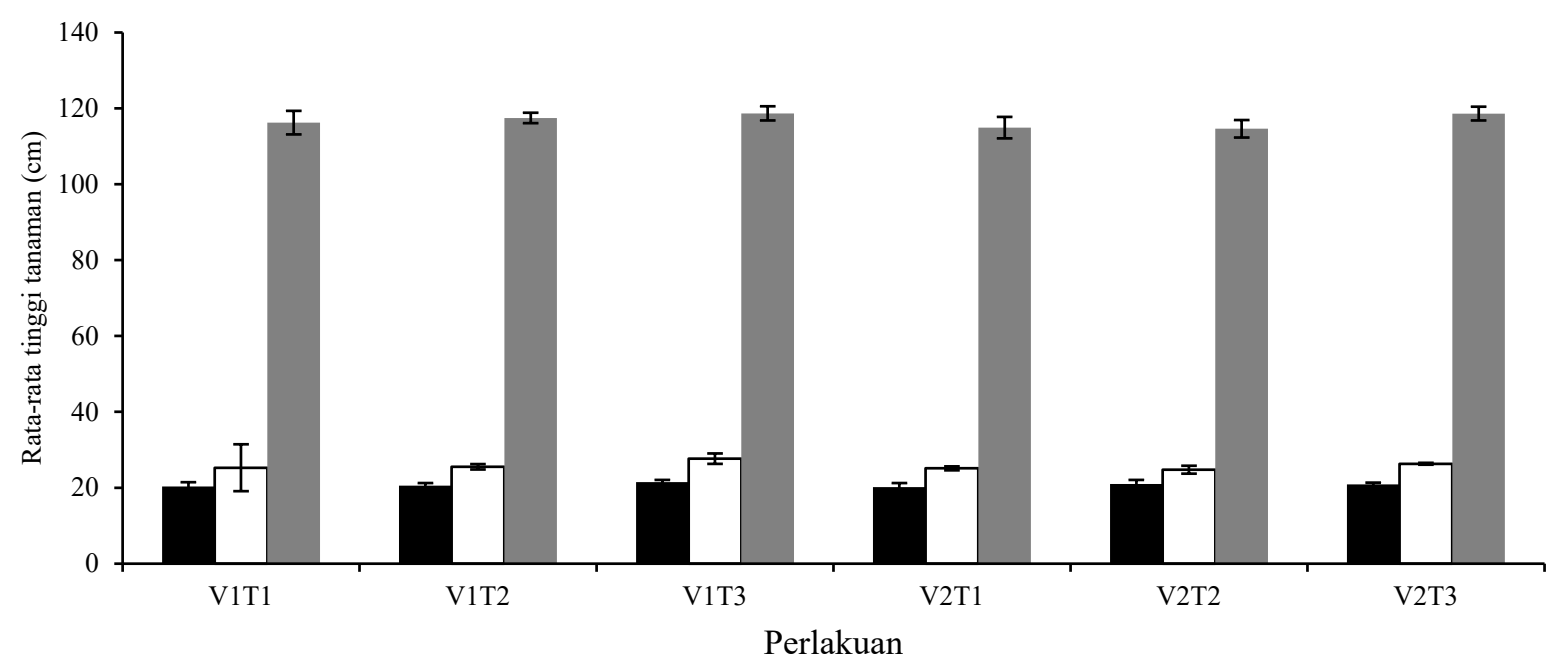

Gambar 1. Rata-rata tinggi tanaman pada umur 14, 21 dan 56 HST dengan teknik penanaman pada berbagai varietas padi. V1 = Inpari 32; $\mathrm{V} 2=$ Inpari 42; T1 = sistem jarwo; T2 = sistem tegel; T3 = manual; Bar \pm S.E.

teknik penanaman tidak mempengaruhi pertumbuhan tinggi tanaman pada varietas Inpari 32 dan Inpari 42. Hasil penelitian Umar et al. (2017) menunjukkan bahwa ratarata tinggi tanaman padi dengan perlakuan mesin tanam rice transplanter tidak berbeda dengan cara konvensional (penanaman secara manual) dengan pola tanam jarwo 2:1 pada lahan pasang surut. Pada pola jarwo $(25 \mathrm{~cm} \mathrm{x} 12.5$ $\mathrm{cm}$ x $50 \mathrm{~cm}$ ) memiliki jarak tanaman yang renggang antar barisan, tetapi memiliki jarak yang rapat dalam barisan. Sistem tanam manual dan tegel $(25 \mathrm{~cm}$ x $25 \mathrm{~cm})$ memiliki jarak tanam yang sama antar barisan dan dalam barisan sehingga memiliki pertumbuhan yang relatif sama. Hasil penelitian Yetti dan Ardian (2010) menunjukkan bahwa perlakuan jarak tanam $25 \mathrm{~cm}$ x $25 \mathrm{~cm}, 30 \mathrm{~cm}$ x $30 \mathrm{~cm}, 35$ $\mathrm{cm} \times 35 \mathrm{~cm}$ dan $40 \mathrm{~cm}$ x $40 \mathrm{~cm}$ pada varietas IR 42 dengan metode SRI tidak berpengaruh terhadap rata-rata tinggi tanaman umur 12 minggu setelah tanaman.

\section{Jumlah Anakan}

Hasil uji lanjut menunjukkan bahwa varietas Inpari 32 memiliki rata-rata jumlah anakan berbeda dengan varietas Inpari 42 pada umur 21 dan 56 HST (Tabel 1). Jumlah anakan sangat berpengaruh terhadap peningkatan produktivitas tanaman karena jumlah anakan dapat berbanding lurus dengan jumlah malai sehingga semakin banyak anakan maka jumlah malai yang bepeluang menghasilkan bulir semakin besar. Sutoro et al. (2015) menyatakan bibit padi dapat menghasilkan anakan primer, sekunder, dan tersier yang setiap anakan dapat menghasilkan malai. Hal ini menjadi gambaran bahwa semakin banyak anakan, maka peluang terbentuknya malai semakin tinggi. Perbedaan jumlah anakan menunjukkan kemampuan varietas untuk tumbuh sesuai dengan potensi genetiknya pada berbagai lingkungan tumbuh. Yetti dan Ardian (2010) menyatakan bahwa jumlah

Tabel 1. Rata-rata jumlah anakan varietas padi dengan berbagai teknik penanaman pada umur 14, 21, dan 56 HST

\begin{tabular}{lccc}
\hline \multirow{2}{*}{ Perlakuan } & \multicolumn{3}{c}{ Jumlah anakan (anakan) } \\
\cline { 2 - 3 } & 14 HST & 21 HST \\
\hline Varietas (V) & & & $17.96 \mathrm{a}$ \\
$\quad$ Inpari 32 & 8.33 & $14.42 \mathrm{a}$ & $15.84 \mathrm{~b}$ \\
Inpari 42 & 8.00 & $12.00 \mathrm{~b}$ & 16.67 \\
Teknik penanaman (T) & & & 16.78 \\
Sistem Jarwo & 8.31 & 12.75 & 17.25 \\
Sistem Tegel & 7.75 & 13.00 & 13.87 \\
Manual & 8.44 & & \\
\hline
\end{tabular}

Keterangan: Angka yang diikuti oleh huruf yang berbeda pada kolom yang sama pada masing-masing perlakuan menunjukkan berbeda nyata dengan analisis BNJ pada taraf $\alpha=5 \%$ 
anakan maksimal pada setiap varietas ditentukan oleh karekter genetik tanaman dan kondisi lingkungan tumbuh. Hasil penelitian Carolina et al. (2015) menunjukkan bahwa varietas Inpari 4 memiliki jumlah anakan tertinggi yang berdeda dengan varietas Mekongga, tetapi tidak berbeda dengan varietas Ciherang.

Faktor teknik penanaman tidak berpengaruh terhadap jumlah anakan tanaman, yang ditunjukkan oleh Tabel 1. Pola tanam dapat mempengaruhi jumlah anakan tanaman jika terdapat perbedaan jarak tanaman karena jarak tanam sangat mempengaruhi persaingan antar tanaman memperoleh unsur hara dan cahaya matahari sehingga jarak tanam yang lebih lebar memiliki jumlah anakan produktif yang lebih banyak. Hasil penelitian pada sistem jarwo 2:1 (25 cm x $12.5 \mathrm{~cm}$ x $50 \mathrm{~cm}$ ) memiliki jumlah populasi 4,800 rumpun per petak percobaan atau 213,333 rumpun per hektar sedangkan sistem tegel pada mesin dan manual $(25 \mathrm{~cm} \mathrm{x}$ $25 \mathrm{~cm}$ ) memiliki jumlah populasi 3,600 rumpun per petak atau 160,000 rumpun per hektar dengan jumlah anakan yang sama pada perlakuan sistem tanam. Hasil penelitian Suhendra (2017) menunjukkan bahwa perlakuan sistem jajar legowo 2:1 dengan jarak tanam lebih lebar (20 cm x 15 $\mathrm{cm}$ x $40 \mathrm{~cm}$ ) menghasilkan jumlah anakan produktif yang lebih tinggi dibandingkan dengan jarak tanam lebih sempit $(20 \mathrm{~cm} \times 10 \mathrm{~cm} \times 40 \mathrm{~cm})$ dan $(20 \mathrm{~cm} \times 13 \mathrm{~cm} \mathrm{x} 40 \mathrm{~cm})$.

\section{Panjang Malai}

Hasil analisis sidik ragam menunjukkan bahwa perlakuan varietas dan teknik penanaman tidak berpengaruh terhadap panjang malai umur 14, 21, dan 56 HST (Tabel 2). Panjang malai dipengaruhi oleh tinggi tanaman karena semakin tinggi tanaman, maka malai yang terbentuk semakin panjang. Hasil penelitian Safitri et al. (2011) memunjukkan bahwa tinggi tanaman padi berkorelasi nyata dan positif terhadap panjang malai tanaman.

\section{Jumlah Malai}

Hasil uji lanjut (Tabel 2) menunjukkan bahwa varietas Inpari 32 memiliki rata-rata jumlah malai berbeda dengan varietas Inpari 42. Jumlah malai tanaman menjadi salah satu indikator produktivitas tanaman karena jumlah malai mempengaruhi jumlah bulir yang terbentuk pada setiap rumpun tanaman. Jumlah malai dan hasil tanaman padi memiliki korelasi positif sehingga semakin banyak jumlah malai yang terbentuk, maka semakin tinggi produktivitas tanaman padi (Misran, 2015). Susilo et al. (2015) menunjukkan bahwa tanaman dengan pembentukan anakan yang banyak berpotensi besar untuk memiliki produktivitas tinggi jika dibandingkan dengan jumlah anakan yang sedikit. Hasil penelitian Ratnawati et al. (2019) menunjukkan bahwa perlakuan varietas Inpari 10, Inpari 38, Inpari 40, Inpari 42, Inpari 43 dan Galur HHZ5-DT1-DT1 tidak berpengaruh terhadap jumlah anakan tanaman sehingga jumlah malai menunjukkan hasil yang sama pada lahan sawah tadah hujan.

\section{Jumlah Gabah per Malai}

Hasil analisis sidik ragam menunjukkan bahwa perlakuan varietas dan teknik penanaman tidak berpengaruh terhadap jumlah gabah per malai (Tabel 2). Jumlah gabah per malai dipengaruhi oleh panjang malai karena semakin panjang malai, maka jumlah bulir gabah yang akan terbentuk semakin banyak. Hasil penelitian menunjukkan bahwa rata-rata panjang malai berbanding lurus dengan jumlah gabah yang terbentuk pada malai, semakin panjang malai maka jumlah gabah yang terbentuk semakin banyak. Hasil penelitian Safitri et al. (2011) menunjukkan bahwa karakter panjang malai berkorelasi nyata dan positif dengan jumlah gabah total per malai dan jumlah gabah isi per malai pada uji 33 galur padi haploid ganda hasil kultur antera dan 3 varietas padi lokal.

\section{Bobot 1,000 biji}

Hasil analisis sidik ragam menunjukkan bahwa perlakuan varietas dan teknik penanaman tidak berpengaruh terhadap bobot 1,000 biji (Tabel 3). Hasil penelitian Safriyani et al. (2018) menunjukkan bahwa bobot 1,000 biji dipengaruhi oleh jumlah gabah bernas dan korelasi positif

Tabel 2. Rata-rata jumlah malai, panjang malai, dan jumlah gabah per malai varietas padi dengan berbagai teknik penanaman

\begin{tabular}{|c|c|c|c|}
\hline \multirow{2}{*}{ Perlakuan } & \multicolumn{3}{|c|}{ Variabel } \\
\hline & Jumlah malai & Panjang malai $(\mathrm{cm})$ & Jumlah gabah per malai \\
\hline \multicolumn{4}{|l|}{ Varietas (V) } \\
\hline Inpari 32 & $17.46 \mathrm{a}$ & 31.37 & 124.50 \\
\hline Inpari 42 & $15.75 b$ & 31.91 & 126.58 \\
\hline \multicolumn{4}{|c|}{ Teknik penanaman $(\mathrm{T})$} \\
\hline Sistem Jarwo & 16.13 & 31.21 & 124.25 \\
\hline Sistem Tegel & 16.50 & 31.83 & 125.88 \\
\hline Manual & 17.19 & 31.89 & 126.50 \\
\hline
\end{tabular}

Keterangan: Angka yang diikuti oleh huruf yang berbeda pada kolom yang sama pada masing-masing perlakuan menunjukkan berbeda nyata berdasarkan analisis BNJ pada taraf $\alpha=5 \%$ 
terhadap peningkatan berat gabah per rumpun pada varietas Inpari 42 dengan perlakuan kombinasi pupuk Urea dan Azolla. Bobot 1,000 biji berhubungan erat dengan tingkat ukuran dan kebernasan biji yang terbentuk pada setiap varietas tanaman dengan teknik penaman yang berbeda. Biji bernas dengan ukuran yang besar akan menunjukkan bobot 1,000 biji yang tinggi sehingga mempengaruhi bobot biji per rumpun dan produktivitas tanaman. Hasil penelitian ini menunjukkan bahwa varietas Inpari 32 dan Inpari 42 dengan teknik penanaman yang berbeda memiliki bobot 1,000 biji yang sama. Hasil penelitian Magfiroh et al. (2017) menunjukkan bahwa perlakuan jarak tanam $20 \mathrm{~cm}$ x $20 \mathrm{~cm}$ dan $25 \mathrm{~cm} \mathrm{x} 25 \mathrm{~cm}$ dengan pola tanam simetris (tegel), jarwo 2:1 dan jarwo 3:1 tidak berpengaruh terhadap bobot 1,000 biji padi varietas Mekonggga.

\section{Bobot Gabah per Rumpun}

Hasil uji lanjut faktor varietas menunjukkan bahwa varietas Inpari 32 memiliki rata-rata bobot gabah per rumpun berbeda dengan Inpari 42 (Tabel 3). Bobot gabah per umpun dipengaruhi oleh jumlah malai, panjang malai dan jumlah gabah per malai. Tanaman yang memiliki jumlah malai yang banyak dan panjang dengan jumlah gabah per malai yang banyak akan menghasilkan bobot gabah per rumpun yang lebih tinggi. Hasil penelitian Safriyani et al. (2018) menunjukkan bahwa bobot gabah per rumpun berkorelasi positif terhadap tinggi tanaman, jumlah malai, jumlah gabah bernas dan bobot 1,000 biji padi varietas Inpari 42 .

\section{Produktivitas (ton hal)}

Hasil uji lanjut faktor varietas menunjukkan bahwa varietas berpengaruh terhadap produktivitas. Varietas Inpari 32 memiliki rata-rata produktivitas berbeda dengan varietas Inpari 42. Hasil analisis menunjukkan bahwa produktivitas tanaman padi dipengaruhi secara langsung oleh jumlah malai dan bobot gabah per rumpun karena semakin banyak malai yang terbentuk pada setiap rumpun makan jumlah bulir yang terbentuk akan semakin banyak dan bobot gabah per rumpun semakain tinggi sehingga maningkatakan produktivitas. Varietas memiliki respon yang berbeda-beda terhadap lingkungan tumbuh sehingga menghasilkan produktivitas yang berbeda-beda. Hasil penelitian Kriswantoro et al. (2018) menunjukkan bahwa perlakuan varietas dengan berbagai cara penanaman benih (alur dan sebar) memberikan hasil yang berbeda terhadap produksi gabah padi pada lahan pasang surut.

Varietas Inpari 32 memiliki rata-rata hasil 6.3 ton $\mathrm{ha}^{-1}$ dan potensi hasil 8.53 ton $\mathrm{ha}^{-1}$, sedangkan Inpari 42 memiliki rata-rata hasil 7.11 ton $\mathrm{ha}^{-1}$ dan potensi hasil 10.58 ton ha $^{-1}$ (Balitbangtan, 2020), dengan capaian hasil pada penelitian ini untuk Inpari 32 sebesar 6.01 ton ha ${ }^{-1}$ dan Inpari 42 sebesar 5.54 ton ha ${ }^{-1}$ (Tabel 3). Adaptasi tanaman menentukan tingkat pencapaian hasil sehingga beberapa varietas mampu memberikan hasil melampaui potensi genetiknya dan sebagian lebih rendah dari potensi genetiknya. Setiap varietas mempunyai kemampuan berbeda dalam memanfaatkan sarana tumbuh dan beradaptasi dengan lingkungannya sehingga berpengaruh terhadap potensi hasil tanaman (Damiri et al., 2017), sejalan dengan hasil penelitian Haryati dan Noviana (2020) menunjukkan bahwa varietas Inpari 38, Inpari 39, Inpari 41, dan Inpari 42 berpengaruh terhadap produktivitas tanaman padi di lahan sawah.

Rata-rata produktivitas menunjukkan bahwa pola jarwo memiliki rata-rata lebih tinggi (6.03 ton $\left.\mathrm{ha}^{-1}\right)$, tegel (5.59 ton ha ${ }^{-1}$ ) dan manual (5.57 ton ha ${ }^{-1}$ ), meskipun memiliki rata-rata jumlah malai, panjang malai, berat gabah per rumpun yang lebih rendah. Hal ini terjadi karena pola tanam jarwo 2:1 pada dasarnya memiliki jumlah populasi tanaman berkisar 213.33 rumpun per hektar sedangkan tegel dan manual berkisar 160,000 rumpun per hektar. Hal ini karena jarak tanam yang lebih sempit pada sistem jarwo 2:1 dibandingkan dengan sistem tegel dan manual yang lebih lebar sehingga jumlah rumpun tanaman per hektar pada jarwo 2:1 lebih banyak. Ikhwani et al. (2013) menyatakan bahwa komponen teknologi cara tanam jajar legowo berpeluang menghasilkan gabah lebih tinggi dibandingkan cara tanam tegel karena menghasilkan populasi lebih banyak

Tabel 3. Rata-rata bobot 1,000 biji, bobot gabah per rumpun, dan produktivitas varietas padi dengan berbagai teknik penanaman

\begin{tabular}{|c|c|c|c|}
\hline \multirow{2}{*}{ Perlakuan } & \multicolumn{3}{|c|}{ Variabel } \\
\hline & Jumlah malai & Bobot gabah per rumpun $(\mathrm{kg})$ & Produktivitas (ton ha $\left.^{-1}\right)$ \\
\hline \multicolumn{4}{|l|}{ Varietas (V) } \\
\hline Inpari 32 & $17.5 \mathrm{a}$ & $29.04 \mathrm{a}$ & $6.01 \mathrm{a}$ \\
\hline Inpari 42 & $15.8 b$ & $28.13 b$ & $5.54 b$ \\
\hline \multicolumn{4}{|c|}{ Teknik penanaman $(\mathrm{T})$} \\
\hline Sistem Jarwo & 16.1 & 28.13 & 6.03 \\
\hline Sistem Tegel & 16.5 & 28.63 & 5.59 \\
\hline Manual & 17.2 & 29.00 & 5.70 \\
\hline
\end{tabular}

Keterangan: Angka yang diikuti oleh huruf yang berbeda pada kolom yang sama pada masing-masing perlakuan menunjukkan berbeda nyata berdasarkan analisis BNJ pada taraf $\alpha=5 \%$ 
pada setiap ukuran lahan, tetapi perlu introduksi varietas lebih adaptif pada kondisi pertanaman rapat karena jarak tanam rapat dapat menurunkan hasil dibandingkan cara tanam biasa/tegel.

Rata-rata bobot 1,000 biji varietas Inpari 32 dan Inpari 42 sebesar $27.1 \mathrm{~g}$ sehingga bobot per biji sebesar $0.027 \mathrm{~g}$ (Balitbangtan, 2020). Kebutuhan benih tanaman padi dengan penanaman 3 (tiga) bibit per lubang tanam, pada sistem jajar legowo 2:1 dengan jumlah populasi 213,333 rumpun per hektar, membutuhkan benih $17.34 \mathrm{~kg}$ $\mathrm{ha}^{-1}$, sedangkan sistem tegel (mesin dan manual) dengan jumlah populasi 160,000 rumpun per hektar, membutuhkan benih $13.01 \mathrm{~kg} \mathrm{ha}^{-1}$. Pada benih terdapat besaran daya kecambah pada fase persemaian sebesar $85-90 \%$ sehingga kebutuhan benih sistem jajar legowo $2: 1$ sebesar $21 \mathrm{~kg} \mathrm{ha}^{-1}$ sedangkan sistem tegel sebesar $16 \mathrm{~kg} \mathrm{ha}^{-1}$ pada persemaian sistem dapog. Pada sistem persemaian di lahan sawah maka jumlah benih yang dibutuhkan lebih besar karena upaya mengantisipasi kekeringan, banjir, serangan hama keong, dan tikus pada saat persemaian. Kebutuhan benih padi pada sistem jajar legowo yang direkomendasikan sebesar $25 \mathrm{~kg}$ ha $^{-1}$ (Balitbangtan, 2016).

Selain itu, penerapan mesin tanam (rice transplanter) secara signifikan dapat menekan biaya produksi dan jumlah tenaga kerja pada saat penanaman. Hasil penelitian Umar dan Pangaribuan (2017) menunjukkan bahwa pada luas satu hektar lahan pasang surut dengan rice transplanter memiliki tingkat efisiensi tenaga kerja yang lebih baik dibandingkan dengan manual (konvensional). Penanaman dengan rice transplanter membutuhkan 3 orang tenaga kerja dengan waktu kerja 6-7 jam tanpa biaya makan, sedangkan secara konvensional membutuhkan 30-35 tenaga kerja dalam waktu 4 jam dengan biaya makan. Hal ini menjadi gambaran efisiensi tenaga kerja dan waktu penanaman untuk proses penanaman pada lahan sawah budidaya.

\section{KESIMPULAN}

Faktor tunggal varietas berpengaruh nyata terhadap jumlah anakan, jumlah malai dan produktivitas padi, sedangkan teknik penanaman tidak berpengaruh terhadap semua variabel pengamatan. Varietas Inpari 32 memberikan hasil terbaik pada jumlah anakan umur 21 dan 56 HST, jumlah malai dan produktivitas (6.01 ton ha' $\left.{ }^{-1}\right)$ tanaman.

\section{DAFTAR PUSTAKA}

[Balitbangtan] Badan Penelitian dan Pengembangan Pertanian. 2016. Petunjuk teknis budidaya padi jajar legowo super. Badan Penelitian dan Pengembangan Pertanian, Kementerian Pertanian. Bogor. ID.

[Balitbangtan] Badan Penelitian dan Pengembangan Pertanian. 2020. Deskripsi varietas unggul padi. Badan Penelitian dan Pengembangan Pertanian, Kementerian Pertanian. Bogor. ID.

[BPS] Badan Pusat Statistik. 2019. Indikator pertanian 2019. Badan Pusat Statistik, Jakarta. ID.
[BKP] Badan Ketahanan Pangan. 2019. Situasi ketahanan pangan dan gizi Indonesia 2019. Kementerian Pertanian, Jakarta. ID.

Carolina, P.S.S., J. Ginting, Meiriani. 2015. Pertumbuhan dan produksi padi sawah pada beberapa varietas dan pemberian pupuk NPK. J. Online Agroekoteknologi 3:1416-1424.

Harnel. 2012. Kajian teknis dan ekonomis alat tanam bibit padi manual (transplanter) modifikasi Balai Besar Pengembangan Mekanisasi Pertanian di Kabupaten Sijunjung, Sumatera Barat. J. Pengkajian Pengembangan Teknologi Pertanian 15:38-46.

Haryati, Y., I. Noviana. 2020. Fenotip dan produktivitas beberapa varietas unggulbarupadipadaagroekosistem lahan sawah di kabupaten Majalengka. J. Pengkajian Pengembangan Teknol. Pert. 23:71-79.

Ikhwani, G.R., E. Pratiwi, Faturrohman, A.K. Makarim. 2013. Peningkatan produktivitas padi melalui penerapan jarak tanam jajar legowo. Iptek Tanaman Pangan 8:72-79.

Kriswantoro, H., E. Safriyani, Purwaningsih, S. Herlinda. 2018. Karakteristik agronomis tiga varietas padi (Oryza sativa L.) pada dua sistem tanam benih di lahan pasang surut. J. Agron. Indonesia 46:140-144.

Magfiroh, N., I.M. Lapanjang, U. Made. 2017. Pengaruh jarak tanam terhadap pertumbuhan dan hasil tanaman padi (Oryza sativa L.) pada pola jarak tanam yang berbeda dalam sistem TABELA. e-J. Agrotekbis 5: 212-221.

Misran. 2015. Keragaan varietas unggul padi sawah di Kecamatan Pulau Punjung, Kabupaten Dharmasraya, Provinsi Sumatera Barat. J. Dinamika Pert. 30:7-12.

Ratnawati, Alfandi, I. Sungkawa. 2019. Respon pertumbuhan tanaman dan hasil beberapa varietas padi sawah tadah hujan (Oryza sativa L.) akibat penerapan teknologi. J. Agroswagati 7:111-121.

Safitri, H., B.S. Purwoko, I.S. Dewi, B. Abdullah. 2011. Korelasi dan sidik lintas karakter fenotipik galur galur padi haploid ganda hasil kultur antera. Widyariset 14 : 295-303.

Safriyani, E., M. Hasmeda, Munandar, F. Sulaiman. 2018. Korelasi komponen pertumbuhan dan hasil pada pertanian terpadu padi-azolla. J. Lahan Suboptimal 7:59-65.

Suhendra, T. 2017. Pengaruh jarak tanam pada sistem tanam jajar legowo terhadap pertumbuhan, produktivitas dan pendapatan petani padi sawah di Kabupaten Sragen, Jawa Tengah. SEPA 13:188-194. 
Susilo, J., Ardian, E. Ariani. 2015. Pengaruh jumlah bibit per lubang dan dosis pupuk N, P dan K terhadap pertumbuhan dan produksi padi sawah dengan metode SRI. JOP Faperta. 2:1-15.

Sutoro, T. Suhartini, M. Setyowati, K.R. Trijatmiko. 2015. Keragaman malai anakan dan hubungannya dengan hasil padi sawah (Oryza sativa L.). Bul. Plasma Nutfah 21:9-16.

Syahri, R.U. Somantri. 2016. Penggunaan varietas unggul tahan hama dan penyakit mendukung peningkatan produksi padi nasional. J. Litbang Pert. 35:25-36.
Umar, S., S. Pangaribuan. 2017. Evaluasi penggunaan mesin tanam bibit padi (rice transplanter) sistem jajar legowo di lahan pasang surut. J. Teknik Pert. Lampung 6:105-114.

Yetti, H., Ardian. 2010. Pengaruh penggunaan jarak tanam terhadap pertumbuhan dan produksi padi sawah (Oryza sativa L.) varietas IR 42 dengan Metode SRI (System of Rice Intensification). J. Sagu 9:21-27. 